\title{
Creative accounting in a global business environment
}

\author{
Armenia Androniceanu ${ }^{1}$, and Lenka Strakova ${ }^{2, *}$ \\ ${ }^{1}$ Bucharest University of Economic Studies, Faculty of Administration and Public Management, \\ Department of Administration and Public Management, 6, Piata Romana, 010374, Bucharest, \\ Romania \\ ${ }^{2}$ University of Zilina, Faculty of Operation and Economics of Transport and Communications, \\ Department of Economics, Univerzitna 1, 01026 Zilina, Slovakia
}

\begin{abstract}
.
Research background: The main essence of financial statements is a true and fair view of accounting because accounting information is an essential source of information about the company. A global business environment that provides scope for selecting existing accounting practices, different techniques, or different methods used in reporting may appear to be beneficial to the business and its accounting. Breach of the accounting principle of a true and fair view of the accounts through the intentional implementation of accounting errors or accounting fraud committed by responsible employees increases information asymmetry between creators and users of accounting information.

Purpose of the article: The paper aims to point out the use of creative accounting in companies existing in the global business environment using a graphical representation of accounting cases using creative accounting techniques, namely Window dressing techniques, and Off-balance sheet techniques.

Methods: In the paper is used the method of description and the comparison method based on which we compare entity that prepares the accountant statements in two variants A and B by using window dressing techniques and off-balance sheet techniques. The achieved results are presented in this paper using a graphical representation.

Findings \& Value added: Through the use of creative accounting techniques such as Window dressing techniques and Off-balance sheet techniques, our goal is to point out the possible manipulation of the company's financial statements by performing accounting cases in terms of maximization variant (A) and minimization variant (B).
\end{abstract}

Keywords: window dressing; off-balance-sheet; creative accounting

JEL Classification: $M 41 ; F 60$

${ }^{*}$ Corresponding author: lenka.strakova@fpedas.uniza.sk 


\section{Introduction}

The correctness of financial statements is important in every company existing in a global business environment. The main essence of financial statements is a true and fair view of accounting [1] because accounting information is an essential source of information about the company, which in the global business environment is used by other internal as well as external entities. [2] Based on the above, it is clear that each of the interest groups expects different values and results to achieve their expected goals. [3] Through various mathematical apparatuses or decompositions of individual indicators, [4] a given company may not always achieve the required results, [5] which results in the use of creative accounting. In certain situations, an enterprise may intentionally pursue objectives to improve the reported information [6] that is reflected in the accounting or financial statements of a particular enterprise. Each accounting system defines a true and fair view of accounting [7], which means that it is not able to interfere in activities such as diversity of business practices, goals, or different situations in which a particular company finds itself in the decision-making process, which is then through qualified estimates and expertise. [8] The judgments of the responsible staff are evaluated and recorded in the accounts of the undertaking. A global business environment that provides scope for selecting existing accounting practices, different techniques, or different methods used [9] in valuation and reporting may appear to be beneficial to the business and its accounting in a global business environment. However, there is also a situation that indicates a breach of the accounting principle of a true and fair view of the accounts through the intentional implementation of accounting errors or accounting fraud committed by responsible employees in a particular company, which increases information asymmetry between creators and users of accounting information. As a result of the violation of the principle of accurate and true presentation of accounting, important accounting information necessary for further decision-making activities in the company is impaired. [10] Creative accounting is a process in which a direct economic transaction takes place to achieve positive accounting results. It also represents the process of purposeful manipulation with the reported data of a specific company. [11] In a global business environment, the practices of individual companies can be divided into those that pursue only the company's goal, while the company works with its accounting information and does not distort the true and fair view of accounting, and those that follow the current or future goals of the company. [12] Manipulation of accounting information to transform the financial statements of companies, which should show a true and fair view of accounting, but their creators try to transform them into a form according to their dispositions and further to those that implement deeper interventions in the accounting of specific companies based on subjective interest and objectives. [13]

In a global business environment, creative accounting is a process in which accountants use their expertise in accounting information manipulation rules to correct a different picture of a company's performance. Creative accounting can be described as an accounting practice that may or may not follow the accounting standards and principles. [14] Author Griffiths [15] defines creative accounting as a process in which companies report results that do not reflect a true and fair view of business transactions, but these companies adjust the transactions according to the desired goals. The profit or loss reported by enterprises is based on adjustments and changes in accounting data. Naser [16] explains creative accounting as a process of modification of economic results from the real picture and towards the desired one results. This can be achieved by improper use, or even by abusing existing rules or omitting other rules. He sees the accounting system in a global environment as an extremely receptive environment for creative accounting. Defining the definition of creative accounting is a very complex issue. Creative accounting means the 
misuse of accounting to better present the company in the financial statements. When preparing and submitting financial statements, it is, therefore, possible to meet human creativity, knowledge, and understanding of accounting theory and practice.

In our paper, we focused on two techniques of creative accounting such as window dressing techniques and off-balance sheet techniques. Window dressing as one of the forms of creative accounting is the manipulation of accounting data. It is a transaction that aims to create a more favourable picture of the financial position in the accounts than is the case. Window dressing as one of the forms of creative accounting is the manipulation of accounting data. This is the kind of transaction management, the aim of which is to create a more favourable picture of the financial position in the financial statements than is the case. Off-balance sheet financing is a practice and method that results in liabilities and assets that would normally be recognized in the balance sheet but recognized in the balance sheets of other entities. Through off-balance-sheet financing, companies strive to achieve a low level of indebtedness and a debt-to-equity ratio. [17]

\section{Methods}

The paper has used the method of description and the comparison method based on which we compare entity that prepares the accountant statements in two variants A and B by using window dressing techniques and off-balance sheet techniques. The achieved results are presented in this paper using a graphical representation.

\section{Results and discussion}

This paper is aimed at the entity that prepares the accountant statements in two variants A and B. Option A reports and compiles financial statements to maximize the economic result and the value of assets. Option B pursues the goal of minimizing the economic result. Using a variety of creative accounting techniques, an entity can pursue identified objectives. Within this paper, we apply accounting cases for window dressing and offbalance-sheet financing. Accounting cases represent example amounts rounded in euros. Graphs and ratios that point to manipulations in the financial statements of companies A and B show a change in the results of the company's financial health assessment.

Table 1. Window dressing techniques.

\begin{tabular}{|c|c|c|}
\hline Account 353 & $\begin{array}{c}\text { Overestimation of the fictitious value of outstanding cash deposits of business } \\
\text { owners, at such a value, can be reported in the balance sheet after several } \\
\text { accounting periods. }\end{array}$ \\
\hline Account 013 & $\begin{array}{c}\text { Created by own activity for trading for 5 years. } \\
\text { The software is priced at historical cost with that costs reported for the } \\
\text { acquisition of software are recorded in the amount which, following the entity's } \\
\text { accounting policies, does not exceed the carrying amount of intangible assets - } \\
\text { software recognized at cost. } \\
\text { The entity valued the software at the maximum value - assigned to the direct } \\
\text { costs of creating the maximum share of overheads spent - 37 064 } € \text { will be } \\
\text { reported in the balance sheet as long-term intangible property. }\end{array}$ \\
\hline $\begin{array}{c}\text { Acquisition of } \\
\text { fixed assets in } \\
\text { the amount of } \\
\text { 37 064 } €\end{array}$ & $\begin{array}{c}\text { Part of the acquisition of property is a loan with 10\% p. m.: } \\
\text { The entity has elected to capitalize on interest until the acquisition to acquisition } \\
\text { prices of tangible fixed assets. The entity has decided not to capitalize on interest } \\
\text { until the acquisition, reported them at cost. }\end{array}$ \\
\hline $\begin{array}{c}\text { Modernization } \\
\text { of fixed assets }\end{array}$ & Replacement of technical improvement for repair- reported in costs. \\
\hline Goodwill & An entity tests asset for impairment, as a result, showed a correction - decrease \\
\hline
\end{tabular}




\begin{tabular}{|c|c|}
\hline & $\begin{array}{l}\text { in value by } 37064 € . \text { The entity does not test, resp. does not reduce the value of } \\
\text { goodwill. }\end{array}$ \\
\hline $\begin{array}{l}\text { Research and } \\
\text { Development }\end{array}$ & $\begin{array}{c}\text { Capitalization of intangible fixed assets. Posting to expenses in the period of } \\
\text { origin. }\end{array}$ \\
\hline $\begin{array}{l}\text { Current assets } \\
\text { valued at own } \\
\quad \text { expense }\end{array}$ & $\begin{array}{l}\text { Direct costs for its acquisition are in the amount of } 37064 € \text {. Administrative } \\
\text { costs, sales costs such as advertising, other overhead costs incurred for } \\
\text { customers, storage costs are in the total amount of } 18532 € \text { : The entity } \\
\text { determines the costs in its calculation in the number of direct costs. } \\
\text { An entity shall include a maximum of indirect costs in the calculation of its } \\
\text { costs. }\end{array}$ \\
\hline $\begin{array}{c}\text { Circular } \\
\text { transactions }\end{array}$ & $\begin{array}{c}\text { The company sold its inventories of goods in the amount of } 37064 € \text { second } \\
\text { company for } 40771 € \text {. At the same time, the company purchased the same } \\
\text { goods from another company for } 40771 € \text {. }\end{array}$ \\
\hline $\begin{array}{c}\text { Parking } \\
\text { transactions }\end{array}$ & $\begin{array}{l}\text { The entity has unsaleable inventories in stock in the amount of } 37064 € \text {. It does } \\
\text { not want to create provisions, so it "parks" inventories in the balance sheet of } \\
\text { another entity, in accounting and for tax purposes recognizes the sale of } \\
\text { inventories and subsequent redemption in the next accounting period. }\end{array}$ \\
\hline $\begin{array}{l}\text { Valuation at } \\
\text { removal }\end{array}$ & $\begin{array}{l}\text { The entity has a choice between the FIFO method, the weighted average, and the } \\
\text { individual valuation: The difference between the FIFO method (difference in the } \\
\text { valuation of inventories }+1853 € \text {, costs }-1853 € \text { compared to the average) and } \\
\text { the weighted arithmetic average. }\end{array}$ \\
\hline $\begin{array}{l}\text { Creation of } \\
\text { provisions for } \\
\text { low-turnover } \\
\text { inventories }\end{array}$ & The entity creates a provision of $50 \%$. An entity does not create a provision. \\
\hline $\begin{array}{l}\text { Short-term } \\
\text { and Long- } \\
\text { term } \\
\text { investments }\end{array}$ & $\begin{array}{l}\text { For long-term investments suitable for sale, the change in market value is } \\
\text { recorded in the revaluation reserve in the amount of } 3706 € \text {. When maximizing } \\
\text { the profit or loss, the entity decides to transfer from investments suitable for sale } \\
\text { in a group of tradable one investment, these are securities with an increase in the } \\
\text { market value of } 1853 € .\end{array}$ \\
\hline Receivables & $\begin{array}{l}\text { They should be reported in the balance sheet depending on the probability of } \\
\text { collection and maturity: The entity estimated the risk of repayment of the group } \\
\text { of overdue receivables in the amount of } 37064 € \text { to } 100 \% \text { and therefore created } \\
\text { a provision in this amount. The entity has not created a provision for these } \\
\text { inventories. }\end{array}$ \\
\hline Bad debts & $\begin{array}{l}\text { In the value of } 37064 €: \\
\text { The entity has decided to write off receivables on a one-off basis, or estimates } \\
\text { their amount (using the direct write-off method or the estimation method): } \\
\text { The accounting unit does not write off receivables from the balance sheet. }\end{array}$ \\
\hline Returns & $\begin{array}{l}\text { The entity recognizes the gross value of the receivable in income from the sale } \\
\text { of goods. An entity shall recognize the adjusted value of the discount receivable } \\
\text { until proceeds from the sale of goods, then an unused discount as a penalty for } \\
\text { later payment of the invoice (there are differences in the structure of revenues - } \\
\text { profitability of sales and activity indicators). }\end{array}$ \\
\hline $\begin{array}{l}\text { Transfer of } \\
\text { short-term } \\
\text { liabilities to } \\
\text { long-term } \\
\text { liabilities }\end{array}$ & $\begin{array}{l}\text { Represents an improvement in the company's liquidity: a transfer in the amount } \\
\text { of } 37064 € .\end{array}$ \\
\hline
\end{tabular}

Source: Made by authors 
Table 2. Off-balance sheet techniques.

\begin{tabular}{|c|c|}
\hline $\begin{array}{c}\text { Reporting } \\
\text { provisions for } \\
\text { uncertain } \\
\text { liabilities } \\
\end{array}$ & $\begin{array}{c}\text { The entity recognizes a provision in the amount of } 37064 € \text {. } \\
\text { The entity does not recognize a provision. }\end{array}$ \\
\hline $\begin{array}{l}\text { Factoring and } \\
\text { its reporting as } \\
\text { a transfer of } \\
\text { receivables to a } \\
\text { third party. }\end{array}$ & $\begin{array}{c}\text { An entity shall recognize as a sale: } \\
\text { It records the write-off of a receivable in the amount of } 37064 € . \\
\text { - Recognizes revenues from sales in the amount of } 2966 € . \\
\text { An entity classifies as a loan: The recorded receivable remains in the balance } \\
\text { sheet in the amount of } 37064 € \text { and a short-term loan (loan) in the amount of } 2 \\
\quad 966 € .\end{array}$ \\
\hline SPE units & $\begin{array}{l}\text { The reason for their creation is tax optimization and also the transfer of assets } \\
\text { and liabilities from the balance sheet - show only liquid assets in the balance } \\
\text { sheet. }\end{array}$ \\
\hline
\end{tabular}

Source: Made by authors

Based on the above transactions in both variants $\mathrm{A}$ (maximization variant) and $\mathrm{B}$ (minimization variant), we can see the differences between the values of the financial statements in the following graphs.

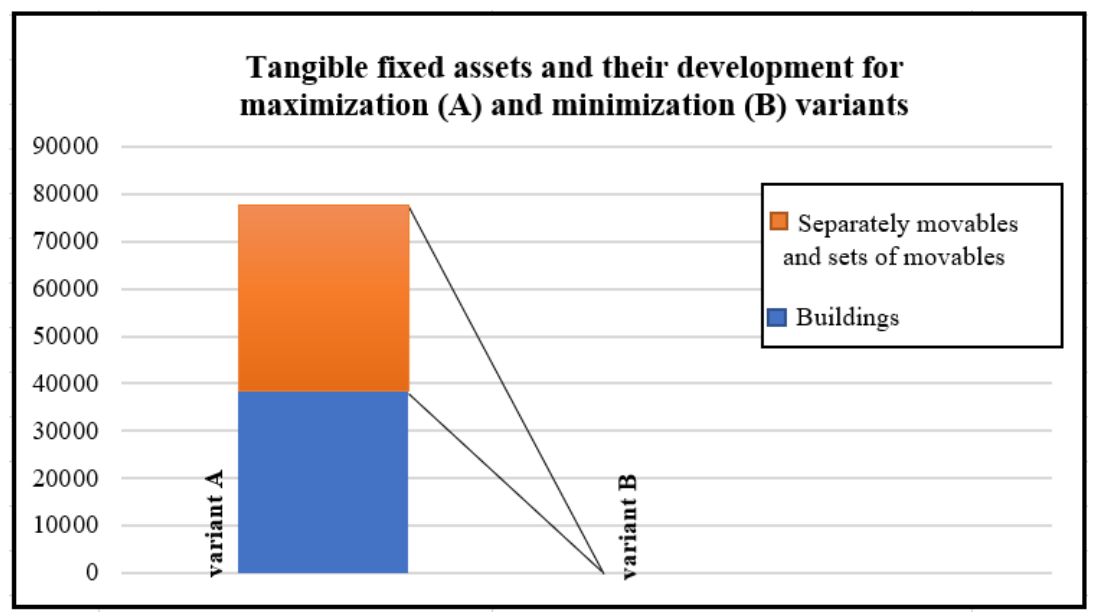

Fig. 1. Tangible fixed assets and their development for maximization (A) and minimization (B) variants in euros.

Source: Made by authors

Based on the chart, we can monitor the value of tangible fixed assets for the maximization variant (A), which indicates the maximization of the values of the entity's assets by implementing creative accounting methods. If we look at the minimization variant (B), we see that, compared to the maximization variant (A), the entity implements creative accounting methods to minimize the value of tangible fixed assets. 


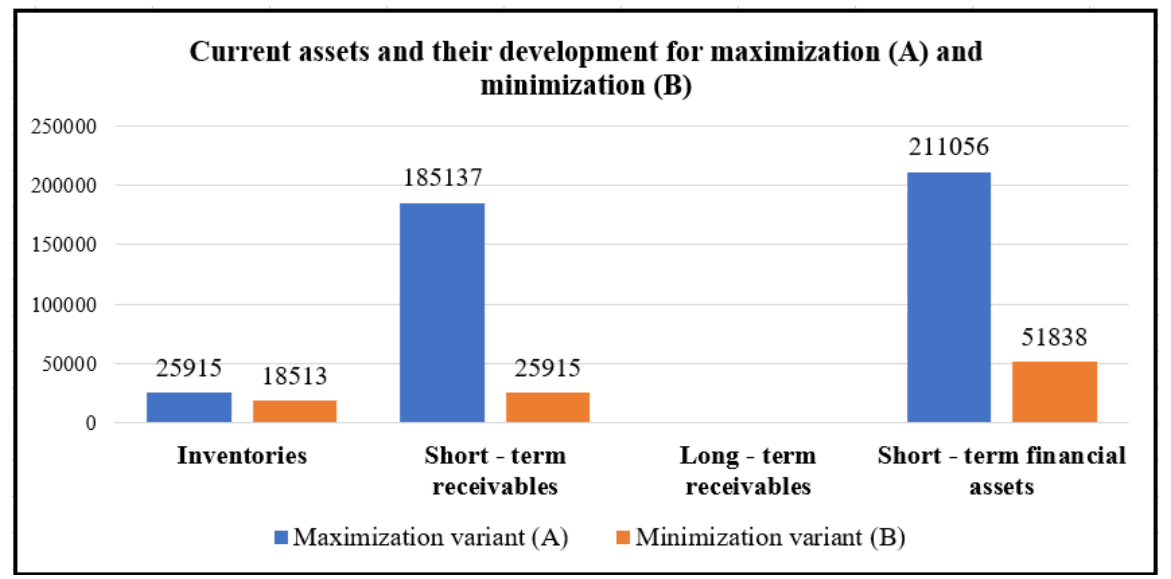

Fig. 2. Current assets and their development for maximization (A) and minimization (B) in euros. Source: Made by authors

Based on the chart, we can monitor the different values of reported current assets, mainly in the area of short-term financial assets or receivables of the entity.

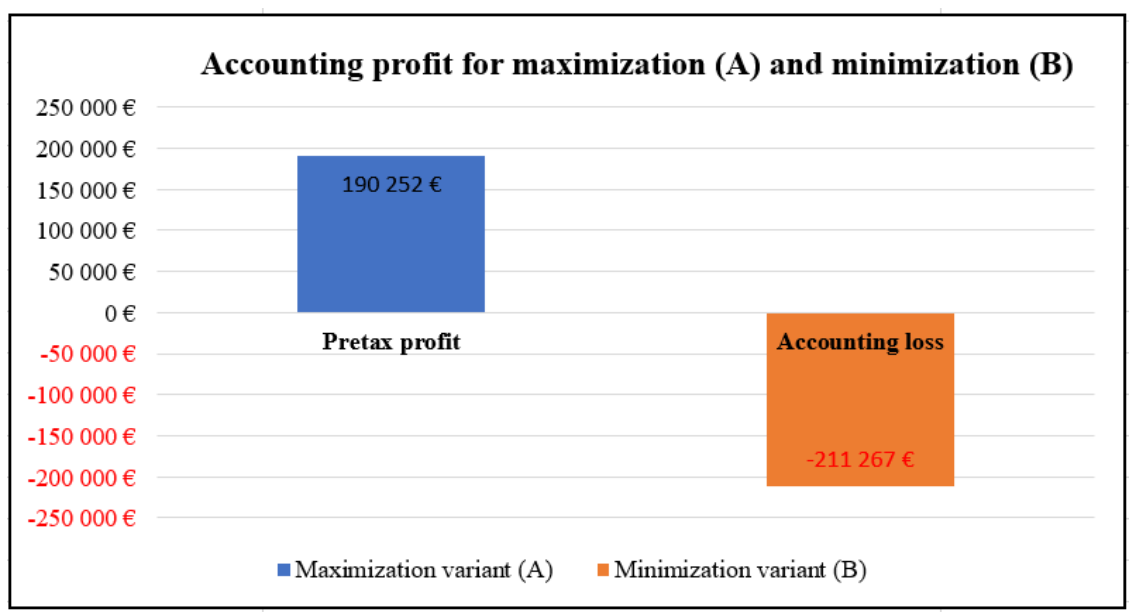

Fig. 3. Accounting profit for maximization (A) and minimization (B) in euros.

Source: Made by authors

The following chart shows the different values of the reported economic result for the maximization variant $(\mathrm{A})$ and the minimization variant $(\mathrm{B})$. In the maximization variant $(\mathrm{A})$ the value of the reported economic result was 190252 euros, but if you look at the minimization variant (B) we see that the value of the reported economic result is negative, which indicates an accounting loss of -211267 euros. Based on the graphical representation, we can say that between the maximization variant $(\mathrm{A})$ and the minimization variant (B) there are differences in the statement of both long-term and current assets and also the economic result.

\section{Conclusion}

In a global environment, the concept of creative accounting is becoming more and more popular. It is related to the effort to reduce costs and maximize profits. On the one hand, 
creative accounting can benefit some entities and, thanks to creative accounting practices, they can adjust their statements to the desired state. On the other hand, creative accounting is an undesirable situation for external entities, for whom financial statements are a very important source of information on the financial health of a company operating in a global environment.

This contribution was aimed at the entity that prepared the financial statements in two variants, A and B. Option A reported and prepared the financial statements to maximize the economic result and the value of the assets. Option B pursued the objective of minimizing the economic result. In this paper, we applied accounting cases for window cover and offbalance-sheet financing. The accounting cases were exemplary amounts rounded to the euro. Based on these accounting cases and their graphical representation, we pointed out the fact that creative accounting in the global business environment is a tool for manipulating the company's financial statements, which indicate a change in the reported values of the company's financial health, taking into account that the company does not perform any other accounting cases involving creative accounting techniques.

This paper was prepared with the support of VEGA 1/0121/20 Research of transfer pricing system as a tool to measure the performance of national and multinational companies in the context of earnings management in conditions of the Slovak Republic and V4 countries which authors gratefully acknowledge.

\section{References}

1. Svabova, L., Kramarova, K., Chutka, J., Strakova, L. (2020). Detecting earnings manipulation and fraudulent financial reporting in Slovakia. Oeconomia Copernicana, 11(3), 485-508.

2. Kliestik, T., Valaskova, K., Lazaroiu, G., Kovacova, M., Vrbka, J. (2020). Remaining Financially Healthy and Competitive: The Role of Financial Predictors. Journal of Competitiveness, 12(1), 74-92.

3. Kliestik, T., Misankova, M., Valaskova, K., Svabova, L. (2018). Bankruptcy prevention: new effort to reflect on legal and social changes. Science and Engineering Ethics, 24(2), 791-803.

4. Raisova, M., Regaskova, M., Lazanyi, K. (2020). The financial transaction tax: an ANOVA assessment of selected EU countries. Equilibrium. Quarterly Journal of Economics and Economic Policy, 15(1), 29-48.

5. Tuffnell, C., Kral, P., Durana, P., Krulicky, T. (2019). Industry 4.0-based Manufacturing Systems: Smart Production, Sustainable Supply Chain Networks, and Real-Time Process Monitoring. Journal of Self-Governance and Management Economics, 7(2), 7-12.

6. Sumiyana, S. (2020). Different characteristics of the aggregate of accounting earnings between developed and developing countries: Evidence for predicting future GDP. Journal of International Studies, 13(1), 58-80.

7. Klein, A., Speckbacher, G. (2020). Does Using Accounting Data in Performance Evaluations Spoil Team Creativity? The Role of Leadership Behavior. Accounting Review, 95(4), 313-330.

8. Rowland, Z., Krulicky, T., Oliinyk, O. (2020). Capital cost quantification model in business activity planning: the evidence of the middle Europe countries. Ekonomickomanazerske spektrum, 14(1), 30-42. 
9. Kovacova, M., Kliestik, T., Valaskova, K., Durana, P., Juhaszova, Z. (2019). Systematic review of variables applied in bankruptcy prediction models of Visegrad group countries. Oeconomia Copernicana, 10(4), 743-772.

10. Pisar, P., Bilkova, D. (2019). Controlling as a tool for SME management with an emphasis on innovations in the context of Industry 4.0. Equilibrium. Quarterly Journal of Economics and Economic Policy, 14(4), 763-785.

11. Taherinia, M., Tavakoli, N., Tavakoli, F. (2018). The Impact of Creative Accounting on the Probability of Fraud in the Companies Accepted in the Tehran Stock Exchange. Industrial Engineering and Management Systems, 17(4), 709718.

12. Akpanuko, E.E., Umoren, N.J. (2018). The influence of creative accounting on the credibility of accounting reports. Journal of Financial Reporting and Accounting, 16(2), 292-310.

13. Parker, J., Ang, L., Koslow, S. (2018). The Creative Search for an Insight in Account. Journal of Advertising, 47(3), 237-254.

14. Remenaric, B., Kenfelja, I., Mijoc, I. (2018). Creative Accounting- motives, techniques and possibilities of prevention. Ekonomski Vjesnik, 31(1), 193-199.

15. Griffiths, I. (1995). New Creative Accounting: How to Make Your Profits What You Want Them to Be. Palgrave MacMillan.

16. Naser, K. (1994). Creative Financial Accounting: Its Nature and Use. Hemel Hempstead: of Accounting and Economics, 17, 281-308.

17. Drabkova, Z. (2016). Models of detection of manipulated financial statements as part of the internal control system of the entity. ACRN Oxford Journal of Finance and Risk Perspectives, 5(1), 230-238. 